\title{
An Effort towards a Common Model for Organizational Change: Synergizing Tools and Processes for Change
}

\author{
Muhammad Nauman Habib ${ }^{1}$, Waseef Jamal ${ }^{2}$
}

\begin{abstract}
The purpose of this study is to review the available literature on organization change and change processes, i.e. organization development (OD), benchmarking, innovation, enterprise resource planning (ERP), business process reengineering, and total quality management (TQM). We focus on salient features of tools and their utility. In the end, we reassess these tools to find out possible interaction and integration among change process so as to analyze from a broader perspective whether they support each other or not, and can they be used simultaneously or not? Literature reveals that there is a possibility of utilizing all these processes in the same organization at different phases of a planned change. On the basis of extant literature, a consolidated model for change is proposed for improved results.
\end{abstract}

Keywords: Change, total quality management (TQM), organization development $(\mathrm{OD})$, innovation, benchmarking, business process reengineering (BPR), enterprise resource planning $(E R P)$

\section{Introduction}

"The only constant is change", the most quoted words by a Greek philosopher, Heraclitus (500 B.C). Change is unpredictable; thus, it requires proper attention of management to utilize change for the betterment of an organization. Rothwell, Prescott, and Taylor (1998) discussed six major trends that force an organization to change (i.e. changing technology, growing globalization, enduring cost restraint, increasing rapidity in market change, growing importance of knowledge capital, and increasing rate and magnitude of change), arguing that each trend is interrelated and has influence on each other; hence it results in complete change. Moreover, Anderson and Anderson (2001) argue that organization change is a forced change in external environment and adoption is a requirement to remain competitive in the market.

Bhandiwad (1998) argued that in 1970s, organizations' focus was towards produc-

1 Assistant Professor, Management Sciences, City University of Science and Information Technology, Peshawar, Pakistan. PhD scholar, Management Sciences, Institute of Management Sciences, Peshawar,Pakistan.Email: habib_nauman@hotmail.com

2 Assistant Professor, Management Sciences, Institute of Management Sciences, Peshawar, Pakistan. Email:waseef.jama@imsciences.edu.pk 
tivity, in 80s the trend shifted towards quality (a rise of Total Quality Management), and since 1990s almost every organization is at least talking about "process improvement", "process redesign" or "process reengineering" as a source (way) to cope with the dramatic changes in technology and competition.

The external environment forces organizations to adjust accordingly. External environment poses threats as well as provides opportunities. However, if the internal system is not adjusted accordingly, then it will result in failure (Amis \& Aissaoui, 2013). There are four major types of change in an internal environment of an organization: structural change, strategic change, process change, and people-oriented change. These changes are interlinked and change in one can lead to force an organization to bring change in the other area as well. Process oriented changes are commonly an attempt to develop overall workflow efficiency and productivity. They may include implementing technological changes, such as robotics in manufacturing or requiring sales teams to begin documenting and reporting activities in a better way. Thus among all the types of changes, process change has a central value and importance in an organization, and is considered as the most difficult of all types of change as well (Habib \& Jamal, 2013).

Scholars have identified that organizational change requires four dimensional change, i.e. change in organizational process, structure or design, change in organizational culture, and change in organizational politics (i.e. change in organizational power distribution etc.). If one wants to bring change in any dimension, it will raise a need for change in the other dimension (as they are interrelated and interdependent). Ignoring one or more dimensions during the change may create problem and will result is failure. Therefore, authors of this study suggest not to use a single method of incorporating change, rather insists on use of multiple methods.

Clarke and Manton (1997) commented that although organizations in 21 $1^{\text {st }}$ century are going through significant changes in process, structure and strategies, there is a distinct absence of quantitative methodology, i.e. tools to estimate their progress in planning, implementing and sustaining change.

Archer and Bowker (1995) stated that markets are changing drastically and these changes are demanding change in production, traditional approach towards innovation, adaptation of latest technology to produce high level of products and services, and to adjust business as per market and global needs. Businesses that do not change their approach are going out of competition and soon will be vanished. There are several observed areas which are the focus of companies including innovation in business processes, improvement in business processes, business process redesign, re-engineering, and business transformation. To ease their efforts towards 
transformation, many companies are hiring consultants and their services (expertise) with hope to get it all done precisely.

Over the half century there are many processes and tools introduced for bringing change in an organization. This study will outline tools and techniques for organizational change and will evaluate their density and to check whether they can coexist or not. This study will help organizations to be more effective in managing the change process with an oversight of do's and don'ts, as well as steps to be taken for a successful change process.

\section{Methodology}

This study is based on review of literature comprising of research articles, working papers and books related to change, processes and tools for change, Organization Development (OD), benchmarking, innovation, Total Quality Management (TQM), Enterprise Resource Planning (ERP), and Business Process Reengineering (BPR). Paper selection criterion was based on the methodology used by Melville, Kraemer, and Gurbaxani (2004). The articles were searched by using key words. The search was limited to impact factor journals, which included International Journal of Quality Science, European Journal of Innovation Management, International journal of operations and production management, business process management journal, strategic management journal, business process reengineering and management journal, journal of European policy, Information system Journal, International Journal of Business and Management, Total Quality Management, Journal of European Public Policy, Benchmarking: An International Journal, and The TQM Magazine. Firstly, articles with the highest citation were selected. Secondly, the method of forward and backward citation was used. Thirdly, these concepts were evaluated to find the common grounds for developing a model that may be adopted for better results. Readers are given an overview of those tools and systems used for bringing change in organization. Secondly, the articles were selected on the basis of most citations and also used the citations used in those researches as a source to reach the breakthrough point and origin of the concepts (ibid). Later these concepts were evaluated to find the common grounds for developing a model that may be adopted for better results. After reading around 600 articles (including books) only those that the articles which were mostly fulfilling the below said objectives were included in this study. The criterion developed was purposive keeping the following research objectives in view:

1. To understand the concept of change and processes used for organizational change.

2. To discuss tools and processes for change and their features.

3. To find possibilities of integration of those processes. 
4. To demystify types of changes and provide brief but comprehensive insight of change, processes and tools for change.

\section{Processes/Tools of Change}

\subsection{Organization Development}

The concept of organization development (OD) was coined by Kurt Lewin in 1940's and since then it is serving as an umbrella term for change in an organization. Cummings and Worley (1997) considered OD as a planned approach to change, aiming to improve firm's performance; while HR being an integral part to the process. Furthermore, OD considers organization to be a complex social system and the interrelated activities of an organization needs to be changed system-wide. Harvey and Millett (1999) stated that OD focuses on organizational culture and processes. Moreover, it considers teamwork and collaboration among management and employees as an important element for bringing change in an organization.

Grint (1997), having his own point of view regarding change called this as "fashion" and every year a new fashion emerges. Every kind of approach, i.e. TQM, BPR, JIT, BSCs (balance score card) and other TLAs (three letter acronyms) are all in line with any related fashion. These approaches itself possess some characteristics that are causing problems. Author further divides his work into two categories, i.e. waves and drowning. According to Grint (1997) there are five major approaches (waves) that can explain change and are further divided into categories. Two of these are rational accounts, two emotional accounts, and one is itself a mirror of fashion. Wave 1 is about the rational idea approach, i.e. if you want to survive, innovate, as it will give you a competitive edge and also increase life of your firm. Wave 2 is about the structural requirements approach, i.e. change in economic structure (change based on economic and technological development). In this phase author is of the opinion that change occurs due to economic, technological, and ideological reasons. Wave 3 is about the charismatic approach, i.e. sometimes more consideration is given to the weakness of organizational leaders while ignoring the requirements of environment. Old fashioned top management tends to be more risk averse. They seem to be unfit in today's dynamic environment and market. As the leadership myth "once a leader will always be a leader" is proved wrong, nonetheless, in most of the cases risk lovers are considered more successful as they are trend setters. Therefore, organizational leadership should take chances if they want to survive in the era of survival of the fittest. Wave 4 is of the distancing approach, i.e. change in living style and differences are increasing among various social classes (especially middle and elite class) and that change is asking companies to change their approach (for example, food, clothing, living style, cars, houses, attitude, ideologies, religions, race etc.). Wave 5 is based on 
the institutional approach, i.e. in most of the situations, companies do not want to give chance to their competitors to change and grow. Hence, whatsoever change is brought by market leader is considered to be of great importance and the rest follow.

Grint (1997) further discusses that change itself might be destructive. Therefore, the second part of his study was based on finding those drowning issues. Drowning issue 1 is about "Rousseau: forced to be free" which states that change requires full commitment of employees and their involvement in each and every stage; however, it requires trust and commitment from management. It may not be possible to ensure employees' commitment, and consequently, lack of commitment from employees will be considered as drowning issue. Second, drowning issue is of "Heisenberg: the uncertainty principle" which states that we cannot measure uncertainty. However, one can assign it a value, i.e. quantitative or qualitative, but it won't be reliable either. Furthermore, with the passage of time, a new phenomenon emerges and whatever is feasible today might not be accepted for tomorrow. Thus, there is always a factor of uncertainty in the business environment. Third drowning issue is "Sartre's pyramid investment" which states that organization will have to shuffle their investment to get improvements; therefore, in some cases downsizing or even delayering will be required. As a matter of fact whenever a change takes place in an organization, employees feel insecure due to fear of losing job because of the fact that adaptation of latest technology decreases the need of employee workforce. Last and important drowning factor is "Weber's bureaucratic nautilus" which is about the organizational structure. As the distribution of power and authority is either centralized or decentralized, both have their own pros and cons. In today's business environment bureaucratic system will cause too much problems for any organization.

It is therefore essential to keep evaluating the underlying basis for change. For a successful organizational change, synergy among the internal and external factors is important. This is not possible without brining essential changes to organization's process, people, structure, strategy, and culture. Choosing the right time, tool, and people are also critical for success of change initiative.

\subsection{Quality and Quality Management}

Martinez-Lorente, Dewhurst, and Dale (1998) conducted a study on the evolution of TQM and stated that TQM is a Japanese approach which originated around 1949 and Americans took notice of TQM around year 1980. Past studies identify that the conceptualization of TQM as the world knows it today started with Hawthorne studies during 1924-1932 to demonstrate the importance of the social and psychological climate in work, followed by American Army who pushed to use sampling method during World War II. In 1950s, many attempts were made to improve working envi- 
ronment which included job enrichment, work redesign, participative management, quality of work life, and worker involvement etc. (Fazel, 2003).

Furthermore in 1960, liberalization of Japanese economy to improve their quality for competing with companies from across the globe took place. Meanwhile, McGregor's theories of X and Y were also introduced. Efforts of Japanese companies and their competitive advantage due to their quality was visible in American companies and it was observed around 1970 (Martínez-Lorente et al., 1998).

In 1985, the Naval Air systems command named its Japanese-style management approach as Total Quality Management (TQM). Thus, in 1987 for the first time a series of ISO standards (namely, 9000) for quality management were introduced. Japanese introduced TQM to improve their productivity and to regain their status after World War II; however, in America this process was known as TQC (total quality control) (Martínez-Lorente, Dewhurst, \& Dale, 1999).

Main attributes (dimensions) of TQM are support from top management, improving customer and supplier relationship, workforce management, employee's attitudes and behavior, process of product design, flow management, reporting quality data, role of the quality department, and benchmarking. Moreover, the common elements found in most of the definitions are top management support, customer and supplier relationships, and employee involvement (Motwani, 2001).

Thus, TQM is a process that aims to provide continuous improvement incrementally by focusing on areas which have the potential to improve quality in every aspect of an organization.

Furthermore, Motwani (2001) identified critical factors and performance measures of TQM (see Table 1). These factors are derived from previous researches and serve as a best tool for managers to consider while planning and implementing TQM. Quality improvement involves all the stakeholders (internal and external); however it does not incorporate radical transformation and focuses on the improvement within existing processes. One of the critical factors of TQM is benchmarking which is another tool for organizational change.

\subsection{Benchmarking}

Another process most commonly referred to and recognized in bringing change in an organization is benchmarking. Riley (2012) defines benchmarking as the process of identifying "best practice" in relation to both products (including) and the processes by which those products are created and delivered. The search for "best practice" can take place both inside a particular industry, and also in other industries. 
Table 1: Critical Factors of TQM

\begin{tabular}{|c|c|c|c|c|c|}
\hline $\begin{array}{c}\text { Saraph et al. } \\
\text { (1989) }\end{array}$ & $\begin{array}{c}\text { Flynn et al. } \\
\text { (1994) }\end{array}$ & $\begin{array}{c}\text { Ahire et al. } \\
\text { (1996) }\end{array}$ & $\begin{array}{l}\text { Zeitz et al. } \\
\text { (1997) }\end{array}$ & $\begin{array}{c}\text { Black and } \\
\text { Porter (1996) }\end{array}$ & Powell (1995) \\
\hline $\begin{array}{l}\text { Top man- } \\
\text { agement } \\
\text { leadership }\end{array}$ & $\begin{array}{l}\text { Top manage- } \\
\text { ment support }\end{array}$ & $\begin{array}{l}\text { Top manage- } \\
\text { ment commit- } \\
\text { ment }\end{array}$ & $\begin{array}{c}\text { Management } \\
\text { support }\end{array}$ & $\begin{array}{c}\text { Strategic } \\
\text { management } \\
\text { and corporate } \\
\text { culture }\end{array}$ & $\begin{array}{c}\text { Executive } \\
\text { commitment }\end{array}$ \\
\hline $\begin{array}{l}\text { Quality data } \\
\text { and reporting }\end{array}$ & $\begin{array}{l}\text { Quality infor- } \\
\text { mation }\end{array}$ & $\begin{array}{c}\text { Internal } \\
\text { quality and } \\
\text { information } \\
\text { usage }\end{array}$ & Use of data & $\begin{array}{l}\text { Quality } \\
\text { improvement } \\
\text { and communi- } \\
\text { cation }\end{array}$ & $\begin{array}{l}\text { Measurement } \\
\text { and zero de- } \\
\text { fects mentality }\end{array}$ \\
\hline $\begin{array}{l}\text { Process man- } \\
\text { agement }\end{array}$ & $\begin{array}{l}\text { Process man- } \\
\text { agement }\end{array}$ & & & $\begin{array}{l}\text { Operational } \\
\text { quality plan- } \\
\text { ning }\end{array}$ & $\begin{array}{l}\text { Process im- } \\
\text { provement }\end{array}$ \\
\hline $\begin{array}{l}\text { Product } \\
\text { design }\end{array}$ & $\begin{array}{c}\text { Product } \\
\text { design }\end{array}$ & $\begin{array}{c}\text { Quality } \\
\text { management } \\
\text { design }\end{array}$ & & $\begin{array}{c}\text { External inter- } \\
\text { face manage- } \\
\text { ment }\end{array}$ & \\
\hline Training & $\begin{array}{l}\text { Workforce } \\
\text { management }\end{array}$ & $\begin{array}{c}\text { Employee } \\
\text { management }\end{array}$ & & & Training \\
\hline $\begin{array}{l}\text { Supplier qual- } \\
\text { ity manage- } \\
\text { ment }\end{array}$ & $\begin{array}{c}\text { Supplier } \\
\text { involvement }\end{array}$ & $\begin{array}{c}\text { Supplier } \\
\text { quality and } \\
\text { performance }\end{array}$ & $\begin{array}{l}\text { Supplier } \\
\text { relationship }\end{array}$ & $\begin{array}{l}\text { Supplier } \\
\text { relationship }\end{array}$ & $\begin{array}{l}\text { Supplier } \\
\text { relationship }\end{array}$ \\
\hline \multirow[t]{2}{*}{$\begin{array}{l}\text { Quality de- } \\
\text { partment }\end{array}$} & $\begin{array}{c}\text { Employee } \\
\text { involvement }\end{array}$ & $\begin{array}{c}\text { Employee's } \\
\text { input }\end{array}$ & $\begin{array}{c}\text { Employees } \\
\text { empowerment }\end{array}$ & $\begin{array}{l}\text { People man- } \\
\text { agement }\end{array}$ & $\begin{array}{c}\text { Employee em- } \\
\text { powerment }\end{array}$ \\
\hline & $\begin{array}{l}\text { Customer } \\
\text { relations }\end{array}$ & Benchmarking & $\begin{array}{c}\text { Supervision } \\
\text { and customer } \\
\text { focus }\end{array}$ & $\begin{array}{l}\text { Customer } \\
\text { orienteers }\end{array}$ & benchmarking \\
\hline
\end{tabular}

Source: Jaideep Motwani, (2001) "Critical factors and performance measures of TQM", The TQM Magazine, Vol. 13 Iss: 4, pp.292-300

Anand and Kodali (2008) argued that the contemporary global changes have forced manufacturing organizations to re-evaluate their management techniques and tools. Benchmarking is considered to be among the practical management tools since 1980's. It has been a prevalent management notion and its significance as a practical tool for developing perilous areas of a business is irrefutable.

Arrowsmith, Sisson, and Marginson (2004) revealed that the common features of benchmarking involve analysis of internal practices and processes in systematic comparison with those of others in order to identify and implement 'best practice'. Bhutta and Huq (1999) considered "best practices" as "the process of identifying the highest standards of excellence for products, services, or processes, and then making the improvements necessary to reach those standards" (p.254). Benchmarking has 
remained part of organizations as a management tool since 1950's and was used for "comparative statistical activity". Benchmarking was used for evaluating basic activities and outcomes i.e. wastage rate, compensation comparison, turnover management etc. In 1970's and 80's, this tool was upgraded and used as "competitive benchmarking" and later on it was used for "generic benchmarking", i.e. for identification of "best practices". Furthermore, it was linked with the business processes like just-in-time (JIT), operations, human resource development (HRD), teamwork, and communication. It was in 1990's when benchmarking was used as a strategic tool (as a learning organization concept) and started taking place as a tool behind successful organizations in the fields of leadership, identification and sustainability of core competencies, and as a standard setter for change management.

There are several types of benchmarking which are extracted by Asrofah, Zailani, and Fernando (2010) from a book written by Bogan and English (1994). These types are mentioned as under:

I. Strategic benchmarking: aims to improve the overall performance of organization by designing long-term strategies. The purpose of strategic benchmarking is to re-assess and re-align the strategies. This helps organizations in standardization and finding the inappropriate strategies which need to be revised.

II. Performance or competitive benchmarking: evaluates the performance and position of key competitors within the sector which helps organizations to identify their position in the industry and act accordingly. This is a very decisive benchmarking type since it provides an insight on industry and rivals which ultimately leads to proper planning.

III. Process benchmarking: this includes process mapping and evaluating existent processes against a firm within industry performing and using similar processes. This helps in achieving improvement in processes.

IV. Functional benchmarking: advocates the help of partners from different sectors to find ways for improving similar functions. With this set of activities, innovation and drastic improvements can be achieved.

V. Internal benchmarking: large corporations operating in several countries use internal benchmarking in order to adopt and implement the best practices of one region organization-wide.

VI. External Benchmarking: involves analyzing organizations that are considered pioneers through their way of doing business. This is, however, a time consuming activity and requires commitment and resources to copy the practices. 
VII.International benchmarking: involves identifying the global leader and following its footprints.

Dattakumar and Jagadeesh (2003) consider benchmarking as an essential tool for continuous improvement of quality. Furthermore, this concept also helps in innovating rather than imitating. Dervitsiotis (2000) concluded that despite the success of benchmarking in continuous improvement and incremental improvement, its scope is now becoming limited due to acceleration in business transformation and social and natural environments. In today's era, a major concern for top management is the expanding scope, i.e. to ensure survival as well as success in the present competitive arena. Benchmarking allows an organization to increase its operational and financial performance as stated by Zeinalnzehad, Sahran, Mukhtar, and Pourrostam (2010). There are seven possible steps in benchmarking process:

1. Plan

2. Research

3. Observe

4. Analyze

5. Adapt

6. Improve

7. Integrate

These steps imply that benchmarking is a time consuming activity. Furthermore, aiming too high with limited resources can be problematic for organization. With TQM approach, striving to master quality by utilizing existing resources, benchmarking may require organizations to do something out of their skin. This may result in over-complication and focusing on irrelevant aspects of business processes. Thus, businesses need to innovate according to their strategic objectives while staying focused, and that too within limited resources.

\subsection{Business Innovation}

Innovation, process innovation, and innovation management, are the topics that prevailed in the business world since World War II. Nonetheless, the context in which they remained associated has changed with almost every passing decade (Ortt $\&$ van der Duin, 2008). The focus of large companies has rapidly shifted towards innovation management. From 1950s till mid-60s, innovation in organizations was 
focused on technology, i.e. adaptation of new technologies and growth (known as technology push); however, very little attention was paid to the entire process or the role of marketplace. During this era, innovation processes were not strategy oriented and were without a comprehensive vision. Till late 70s innovation was used for growth, a process through which companies can attain economies of scale, way of achieving competitive edge via diversification, and a process to reduce financial risks. This period was known as "market pull" (need-pull) where technological changes were rationalized and customers' needs were given more importance. Innovations in 70 s were mostly customer driven; thus, $R \& D$ was gaining much attention. However, a disadvantage of innovation in this phase was negligence of long-term innovation, focus on evolutionary improvements rather than breakthroughs, and most importantly, vision and strategies were lacking. During 1980s and 90s, the trend shifted towards cost control and reduction; thus, innovation in this phase was used as a tool for efficiency, structural changes, and decentralization. In this era, technology push and market pull were combined which resulted in divergence from organizational innovations. Since then, innovation is used for developing core competences, strategic alliances and networking, team based structures, and supply chain development. These innovations are known as innovation in alliances, integrated innovation, and new business development (NBD). However, innovation in this decade is becoming too complex and thus, is resulting in unmanageability (Castellani \& Zanfei, 2003; Miller, 1994; Niosi, 1999).

Innovation activities are forced by external environment including country's policies and competition pressure. In fact in today's era of globalization, innovation is necessary because of international market and competition (Carlsson, 2006).

"The inventions are necessary seed for innovations, but the inventions do not inevitably lead to the innovation" (Trott, 2008, p. 76). "Innovation is mostly regarded as the commercial and practical application of ideas or inventions"(Varjonen, 2006, p. 29). Innovation can possibly be divided into four types: product or service innovations, process innovations, marketing innovations, and organizational innovations (OECD, 2005) (see table below).

Innovation is an essential component for organizational change. It stresses on adaptation of latest trends and technology for bringing efficiency and effectiveness (Abdi, Zarei, Jamshid, \& Parvin, 2011; Carlsson, 2006; Ortt \& van der Duin, 2008). 
Table 2: Types of Innovation and its Characteristics

\begin{tabular}{|c|c|c|}
\hline $\begin{array}{c}\text { Type of Innova- } \\
\text { tion }\end{array}$ & Characteristic \\
\hline $\begin{array}{c}\text { Product or Service } \\
\text { Innovation }\end{array}$ & $\begin{array}{c}\text { A product innovation is the introduction of a product or service that is new } \\
\text { or significantly improved with respect to its characteristics or intended uses. }\end{array}$ \\
\hline Process Innovation & $\begin{array}{c}\text { A process innovation is the implementation of a new or significantly im- } \\
\text { proved production or delivery method. Process innovation can be intended to } \\
\text { decrease unit cost of production or delivery, to increase quality, or to produce } \\
\text { or deliver new or significantly improved products. }\end{array}$ \\
\hline Marketing Inno- & $\begin{array}{c}\text { A marketing innovation is the implementation of a new marketing method } \\
\text { involving significant changes in product design or packaging, product place- } \\
\text { ment, product promotion or pricing. Marketing innovations are aimed at } \\
\text { better addressing customer needs, opening up new markets, or newly position- } \\
\text { ing a firm's product on the market, with the objective of increasing the firm's } \\
\text { sales. }\end{array}$ \\
\hline Organizational & $\begin{array}{c}\text { An organizational innovation is the implementation of a new organizational } \\
\text { method in the firm's business practices, workplace organization or external } \\
\text { relations. Organizational innovations can be intended to increase a firm's } \\
\text { performance by reducing administrative costs or transaction costs, improv- } \\
\text { ing workplace satisfaction (and thus labor productivity), gaining access to } \\
\text { non-tradable assets (such as non-codified external knowledge) or reducing } \\
\text { costs of supplies. }\end{array}$ \\
\hline
\end{tabular}

\subsection{Enterprise Resource Planning (ERP)}

In 1980's the concept of enterprise resource planning (ERP) was coined in US, defined by American Inventory and Production Control System (APICS) dictionary as "An accounting oriented information system for identifying and planning the enterprise-wide resources to make, ship and account for customer orders". ERP is computer based application, used for the management of internal and external resources, i.e. fix assets, financial resources, and human resources etc. Among many trends set by ERP, the major contribution was the introduction of E-commerce which really boosted the use of Information Technology (IT) and Information System (IS) in an organization.

He (2004) in his study stated that ERP aims at integrating functional-area information systems within a company into a coherent, enterprise-wide, and web-enabled network. Its implementation is especially challenging to enterprises in China because of high implementation costs, technical complexity, lack of information technology infrastructure, lack of well-trained employees, lack of incentives to state-owned enterprises, and a corporate culture different from that in the West.

Huang and Palvia (2001) are also of the opinion that there is a growing need to 
implement a total business solution which supports major functionalities of a business. ERP is intended to encounter these needs, and has been extensively accepted by organizations in developed countries. The major barrier in the implementation of ERP in developing countries is of its external environment, i.e. economic condition, cultural issues, and basic infrastructure issues. Authors provided a comprehensive framework for the implementation of ERP.

Sheua, Yenb, and Krumwiedec (2003) found that culture and language, government and corporate policies, management styles and regulations are amongst key features that have been taken for in order to successfully implement ERP. Martinsons (2004) reported that within the same country, different organizations can behave differently because of their government policies and internal factors of organization.

This was the first time that a proper procedure was developed and had dramatic results in the 1980's and 90's. Later on, researchers and scholars designed other processes by studying and evaluating the outcomes as discussed by McKay and Radnor (1998). ERP was soon merged and replaced by a high profile and intense mechanism of business process reengineering (BPR) where IT is its integral part.

\subsection{Business Process Reengineering (BPR)}

Hammer (1990) is considered as the father of BPR who explored and brought BPR to the world. BPR is said to be a new approach for the process management that brings radical change (improvement) in organizational performance. Hammer and Stanton (1995) addressed the forces that are driving firms to bring radical change, i.e. customer, competition, and change, and provided a tool (called business process reengineering) to deal with the requirements of these driving forces.

Cao, Clarke, \& Lehaney (2001) consider BPR as a tool for change, increasing productivity, reducing cost, and improving satisfaction of customers and quality of products produced. Researchers argue that most of the previous studies are based on single aspect of BPR, while this process is having more than one fold of issue that needs to be discussed. Thus, it may not be a single reason that causes high rate (about 70\%) of failure in BPR implementation, rather there may be several reasons that contribute to the failure of implementing change successfully (Ahmad, Francis, $\&$ Zairi, 2007). BPR is a process that is used for bringing radical change in an organization; thus, different approaches should be used for different dimensions of change and the interaction of different dimensions should be considered while bringing change. Therefore, several researchers are of the opinion to educate the change and provide training before it takes place (Abdolvand, Albadvi, \& Ferdowsi, 2008; Habib $\&$ Wazir, 2012; Sentanin, Santos, \& Jabbour, 2008). BPR is equally applicable in 
public and private sectors (production as well as services sectors); however, there is a difference in availability of resources and their utilization. Furthermore, it can be used with modeling techniques as well as be customized depending upon the need and expectations of the firm (MacIntosh, 2003).

Muthu, Whitman, and Cheraghi (1999) in their study focused on presenting a consolidated methodology for BPR. Their approach was based on the shortcomings of previous studies and models (see Table 3) (presented by Harrison \& Pratt (1993), Furey (1993)) and provide their own model for BPR. Muthu et al. (1999) stated that $\mathrm{BPR}$ is a process for those who want 10 times improvement; hence, it should not be used for minor improvement in business processes. Before incorporating BPR, the authors insist on having process maps (department wise) as an important tool for getting insight of the area that needs radical change.

Table 3: BPR Process

\begin{tabular}{|c|c|c|c|}
\hline Activity & Furey (1993) & \multicolumn{2}{|c|}{ Harrison and Pratt (1993) } \\
\hline & Set Direction & \multicolumn{2}{|c|}{$\begin{array}{c}\text { Determine Customer Requirements \& Goals for } \\
\text { the Process }\end{array}$} \\
\hline & Baseline and Benchmark & \multicolumn{2}{|c|}{ Map and Measure the Existing Process } \\
\hline & Create the Vision & \multicolumn{2}{|c|}{ Analyze and Modify Existing Process } \\
\hline & Launch Problem Solving Projects & \multicolumn{2}{|c|}{ Design a Reengineered Process } \\
\hline & Design Improvements & \multicolumn{2}{|c|}{ Implement the Reengineered Process } \\
\hline \multicolumn{4}{|c|}{ Implement Change } \\
\hline & Embed Continuous Improvement & & \\
\hline \multirow[t]{7}{*}{ Activity } & Manganelli and Klein (1994) & Mayer et al. (1998) & Underdown (1997) \\
\hline & Preparation & Motivating Reengineering & $\begin{array}{l}\text { Develop vision } \& \\
\text { strategy }\end{array}$ \\
\hline & Identification & Justifying Reengineering & Create desired culture \\
\hline & Vision & Planning Reengineering & $\begin{array}{l}\text { Integrate \& Improve } \\
\text { enterprise }\end{array}$ \\
\hline & Technical \& Social design & $\begin{array}{l}\text { Setting up for Reengi- } \\
\text { neering }\end{array}$ & $\begin{array}{l}\text { Develop technology } \\
\text { solutions }\end{array}$ \\
\hline & Transformation & $\begin{array}{l}\text { As Is Description \& } \\
\text { Analysis: }\end{array}$ & \\
\hline & & $\begin{array}{l}\text { To-Be Design and Vali- } \\
\text { dation }\end{array}$ & \\
\hline
\end{tabular}


Abdi et al. (2011) conducted study on bringing innovation concept to business process redesign methodology by using Dubin's methodology for creating innovation models. By innovation authors mean that BPR changes organization's previous structures and processes, and bring new processes in an innovative manner. Furthermore, authors claim in this paper that soft issues of BPR are not discussed previously. However, there are number of studies discussed above in literature based on soft issues of BPR. On the other hand, authors stated a significant statement that BPR has yet to figure out a unified methodology. They concluded their study on the point that innovation process needs to be inducted into the process of business process redesign and it will lead to success of BPR (Habib, 2013).

\section{Searching for Common Ground}

Having reviewed the literature on change, processes, and tools for change, some very basic and potent questions that arise and need answers are, "whether these tools can co-exist? Can they be used collectively? What will be the output if they are used as a single process?"

To answer these questions, literature is reviewed once again with the following findings:

- Martínez-Lorente et al. (1999) concluded in their study that TQM and business innovation can co-exist and TQM process does not obstruct business innovation. Furthermore, the dimensions of TQM can easily help an organization to become more innovative.

- Deros, Yusof, and Salleh (2006) suggested that successful implementation of benchmarking requires a follow through by TQM. Therefore, benchmarking serves as a roadmap for TQM where the standards are met via continuous improvement programs.

- NG, IP, and LEE (1999) are of the opinion that ERP and BPR are the two widely used tools for sustainability and competitive edge. Both of these tools utilize IT and IS for modernization and adaptation of latest technology. To achieve ground breaking results, it is recommended to use ERP and BPR together, where BPR will serve the broader perspective and ERP will serve as a tool for connecting all the organization's activities.

- IT is an integral part of BPR. Hence BPR can be very useful in implementing ERP system in an organization. Similarly, ERP and e-commerce can be used as a constructive ground for BPR implementation (Subramoniam, Tounsi, \& Krishnankutty, 2009). 
- OD, TQM and BPR all aim to increase organizational efficiency, but attempt to do this through very different means. The key driver can be a similarity between the approaches, as most organizations implement change as a way of dealing with a particular problem (Harvey \& Millett, 1999).

- Salegna and Fazel (1996) argue that although TQM and BPR are two prevalent techniques used for change, but most of the efforts (to transform this effort as a successful project) have turned out as a failure. Authors justify by stating that the lack of integrated framework for implementing those projects may result in failure. Furthermore, the lack of alignment with company's plan (vision and mission), competitive environment, culture of organization and its strategic objectives can also result in failure of change initiative.

- Many of the management teams consider TQM and BPR as mutually exclusive and choose one of them. But Salegna and Fazel (1996) state that quality and reengineering should be unified for sound results. Both TQM and BPR will provide successful results only when they are properly linked with strategic objectives of organization and properly planned. However, there is a difference between the tools and techniques and the areas that are covered by these approaches. At the same time, both are known for its payoffs, i.e. reduced time-cycle, cost efficiency, customer and employee satisfaction.

- Many quality advocates and researchers support the notion that a short-term, radical change achieved through BPR programs should be followed by TQM's long-term continuous improvements (Fazel, 2003).

- For the success of both BPR and TQM, organizational executives are required to understand and create supportive culture and realistic expectations from both processes. Common attributes of TQM and BPR consist of empowering employees, teamwork and development of cross functional team, improvement in the quality, change in process and human behavior, and focus on the interest of customers. The key difference between the two is that TQM is people oriented management system that aims to increase customer satisfaction by reducing cost of production and improving quality, whereas BPR requires radical change and utilizing latest (upgraded and IT based technology) trends, bring change in design of work, strategies, policies and the structure that support the workflow which ultimately improve productivity. (Senthil, Devadasan, Selladurai, \& Baladhandayutham, 2001)

- GonzaÂlez-Benito, Martinez-Lorente, and Dale (1999) pointed that TQM revolves around continuous improvement and to facilitate change on regular basis while 
BPR is the concept that requires radical change throughout the organization (i.e. process re-design, process re-engineering and a fundamental rethinking of the business). Therefore, these processes can either be used interchangeably or used together, as the aim of both concepts is based on change and its effective implementation.

- Lee and Asllani (1997) conducted a study on the compatibility of TQM and BPR and argued that although both approaches are significantly different from each other, however, these approaches are designed for improving organizational performance. There are some commonalities in these approaches, i.e. both processes aim to improve quality, both require involvement and support from top management, strive to achieve customer satisfaction and, both require changes in organizational culture and structure to achieve their objectives. Besides these common attributes, there are few major differences among BPR and TQM such as TQM requires gradual and adoptive changes to achieve competitive advantage, while BPR aims for radical change (a change that cannot be copied easily) to attain competitive edge. Furthermore, TQM is a continuous process that requires a lot of time (as it is a long term process) to create value for the firm, and also requires to create right type of culture which takes much longer time to readjust the organizational culture, while BPR on the other hand aims for radical change and typically takes short time period. However, BPR also needs to create right organizational culture as well. Also in TQM, initiative of change is basically identified at any organizational level (mostly from lover level) and quality improvement process is carried out with the help of employees (bottom up approach), while BPR on the other hand is associated with adaptation of latest technology which may lead to employees layoff; thus, this approach is having top to bottom approach.

- There are three categories of scholars based on their views regarding BPR and TQM. First, (Vitiello) those who do not consider BPR as a new approach and claim that it is brought from existing methodologies of process automation and total quality. Second group (Hammer) considers BPR as a totally new approach as it involves radical change. The third group (Hodgetts, Braithwaite) of scholars accepts the difference of BPR and TQM; however, they are of the opinion that organizations should utilize and combine both approaches for sustainable results and called it as "organization's strategic approach".

- Macdonald (1995) argues that BPR and TQM together will ensure success of an organization. Moreover, author is of the opinion that BPR is an approach that uses three approaches to change, i.e. process improvement, process redesign and process re-engineering, as shown in Figure 1: 


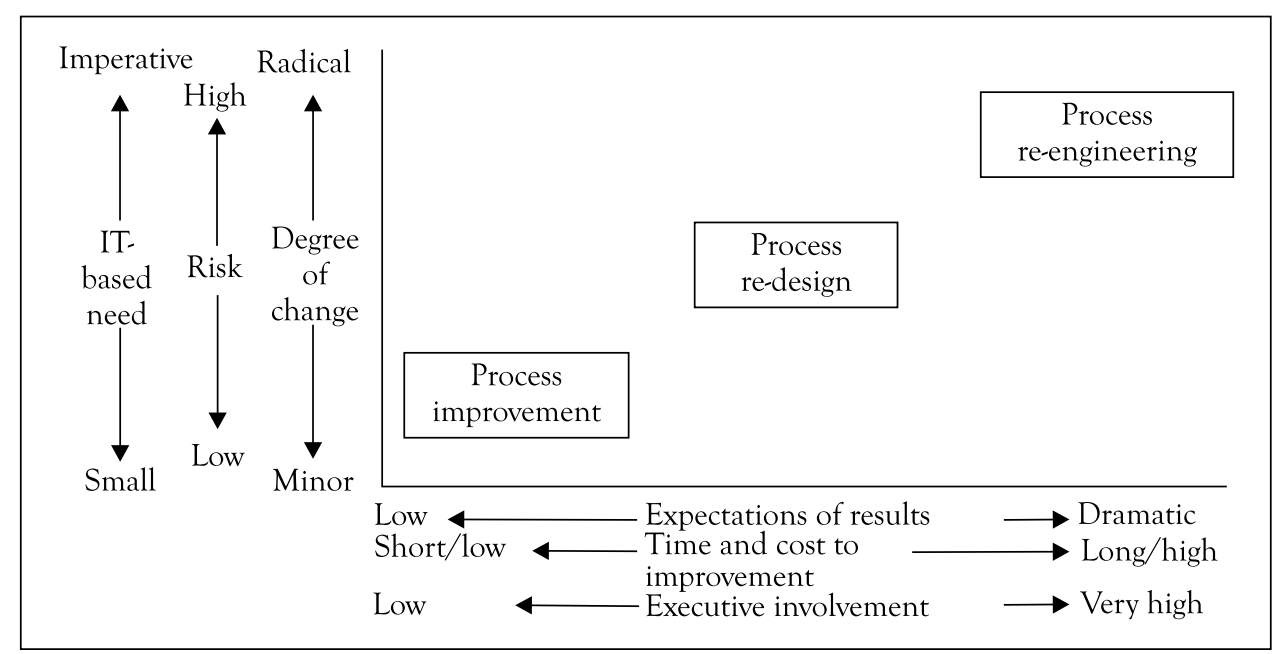

Source: Macdonald (1995)

Figure 1: Approaches to Change

- Al-Mashari, Irani, and Zairi (2001) also focused on integrated approach rather than using BPR individually and stated that this is the way to control the chances of failure in radical change. A study based on the firms in US and Europe revealed that benchmarking, TQM, and change management tools are commonly used as integrated tools with BPR. In US however, TQM is mostly combined with BPR (with the mean of 3.37) while in Europe, change management is most frequently used with BPR (with the mean of 3.26). Change management is a tool used as the second most commonly integrated tool with BPR in US while TQM is ranked $2^{\text {nd }}$ in Europe. Benchmarking is considered as least integrated tool in both US and Europe. Furthermore, the in-depth analysis of all those integrated approaches showed some interesting results; Al-Mashari et al. (2001) survey findings suggest that there are practical examples of integrated approaches in USA as well as in Europe. (See Table 4)

After studying the tools used both for BPR and TQM, it is observed that there are several tools and techniques which are common for both of these processes, i.e. customer orientation, benchmarking, JIT techniques, cooperation and collaboration (teamwork), employee empowerment, training, and quality improvement (Senthil et al., 2001).

Selladurai (2002) proposed a model for organizational profitability, productivity, and performance (PPP), where focus of the model was on the quality of products and services as a critical element for organizational success. Furthermore, to improve a firm's PPP, researcher also recommended to focus on people (a most valuable re- 
Table 4: Approaches of Change adopted in USA

\begin{tabular}{|c|c|c|c|c|c|c|}
\hline \multirow{2}{*}{ Approach } & \multicolumn{2}{|c|}{ Overall } & \multicolumn{2}{c|}{ USA } & \multicolumn{2}{c|}{ Europe } \\
\cline { 2 - 7 } & Mean & Rank & Mean & Rank & Mean & Rank \\
\hline $\begin{array}{c}\text { Combining short-term improve- } \\
\text { ment with long-term innovoation }\end{array}$ & 2.97 & 1 & 2.97 & 1 & 2.96 & 1 \\
\hline $\begin{array}{c}\text { Making continuous improvement } \\
\text { come after radical process change }\end{array}$ & 2.92 & 2 & 2.90 & 2 & 2.93 & 2 \\
\hline $\begin{array}{c}\text { Using a revolutionary design } \\
\text { of change, and an evolutionary } \\
\text { implementation }\end{array}$ & 2.45 & 3 & 2.53 & 3 & 2.36 & 3 \\
\hline $\begin{array}{c}\text { Using BPR for high level design of } \\
\text { processes \& TQM for a detailed } \\
\text { design }\end{array}$ & 2.40 & 4 & 2.50 & 4 & 2.29 & 4 \\
\hline $\begin{array}{c}\text { Creating a process portfolio, where } \\
\text { processes are classified based on } \\
\text { types of changes required whether } \\
\text { they are radical or incremental }\end{array}$ & 2.16 & 5 & 2.21 & 5 & 2.11 & 5 \\
\hline Wavering between TQM and BPR & 2.12 & 6 & 2.17 & 6 & 2.07 & 6 \\
\hline
\end{tabular}

source), customer satisfaction, productive business processes (productivity in business processes may be enhanced through the incremental change improvements of TQM and the rapid, innovative, revolutionary change implementations of BPR), adaptability (organization must be flexible to meet changing demands and expectations in the marketplace), and progressive leadership (strategic vision and management leadership including top management levels will blend everything together).

Light (2004) is of the opinion that employees' involvement in change is vital. Moreover, productivity in business processes may be enhanced through the incremental change improvements of TQM and the rapid, innovative, revolutionary change implementations of BPR. The use of IT and knowledge management to enhance productivity will be the wave of the future. Managing new business process means developing new products concurrently and adapting the organization's resources and product development processes to implement this strategy.

Hence, from the literature (reviewed), it is clear that change is not going to be obsoleted; therefore, companies will always strive to utilize these tools for survival and growth. The utilization of these tools however, differs from firm to firm and nature of businesses. Some companies use these processes individually while some firms combine them for better results. There is still much to explore and learn as organizations are facing new challenges and changes with every passing day. Therefore, organizational 
change cannot be restricted to a single process of change, i.e. a company may either need to utilize a single process and tool or it may plan a comprehensive strategy for ongoing change activities which may comprise of strategic management, OD, benchmarking, innovation, ERP, and BPR as steps (phases) of the same process.

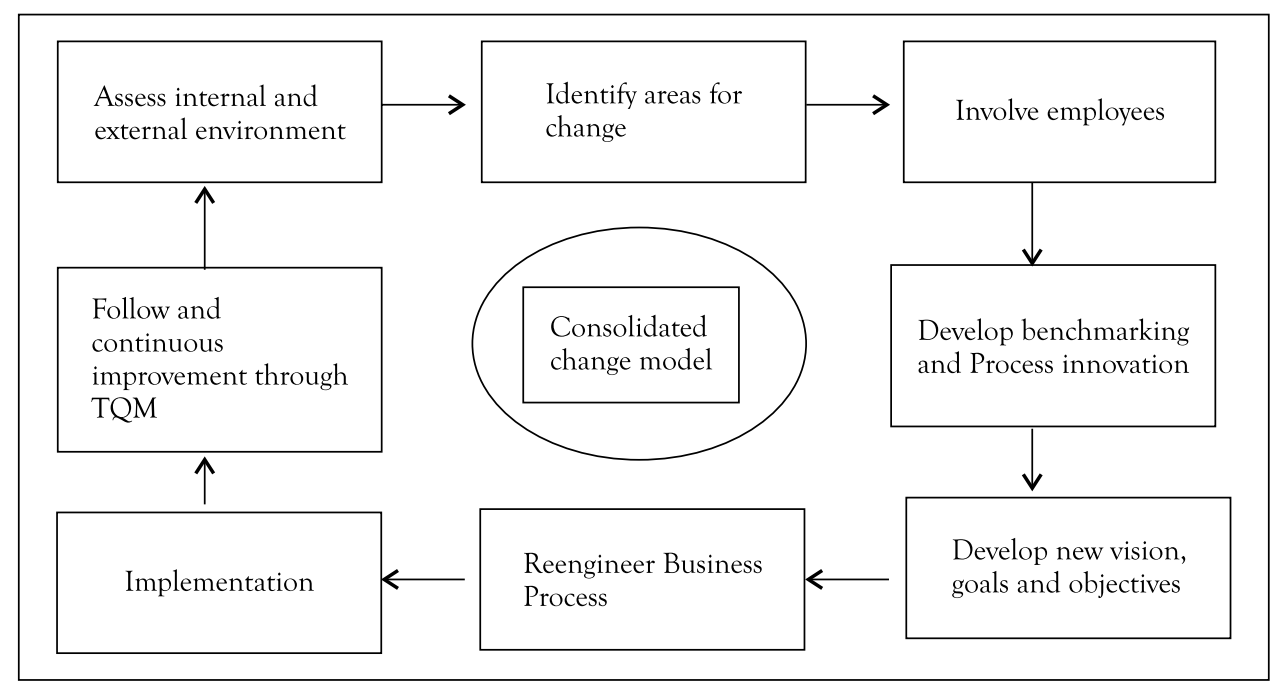

Figure 2: Consolidated Model for Change

After reviewing the literature on planned change, tools, and processes, a consolidated model for change in organization is proposed.

Assess internal and external environment: The first step for organizational change is that it may either be by internal needs (HR, communication, organization culture, adaptation of new technology and IT), weaknesses (problems) or it may be forced from the external environment (competition, customer needs, change in political structure etc.). Thus, it is necessary to assess internal as well as external environment before starting the change process (Abdi et al., 2011).

Identify areas for change: Every firm needs a set of direction to utilize its energy properly; therefore, once environment has been assessed, the next phase involves identification of broad areas that possibly need to be changed (Furey, 1993). Recognizing the need for change requires an evidence based management, where the management should undertake in-depth analysis (to identify loopholes) of whole organizational processes so that it can list down all the possible functional areas of that organization which need to be changed (Babbar \& Aspelin, 1994; Pfeffer \& Sutton, 2006).

Involve employees: Involve your $\mathrm{HR}$ as much as possible as it will ease the implementation process and also achieve goals and objectives. Developing teams, brainstorming sessions, and feedback will help in reducing resistance to change in 
later stages (Jaideep. Motwani, 2001). Ahmad et al. (2007) believe that employees' empowerment and involvement will improve level of motivation and will also help in reducing fear of losing job. Furthermore, it will also help in employees' readiness for change and eventually in reengineering motivation (Abdi et al., 2011).

Benchmarking and Process innovation: Benchmarking will help an organization to identify the best practices and set the highest standards to survive and compete in a dynamic business environment (Anand \& Kodali, 2008; Arrowsmith et al., 2004; Riley, 2012). Furthermore, benchmarking will help an organization in innovation as well as in setting goals and objectives (Dattakumar \& Jagadeesh, 2003). An organization should focus on all types of benchmarking to cover its all aspects which will eventually lead to proper goal setting (Furey, 1993; Martínez Lorente et al., 1999; Zeinalnzehad et al., 2010). At the similar stage, firms need to select the innovation that best suits their requirement, e.g. technology, market pull innovation, customer driven, innovation for strategic alliance, developing core competencies etc. (Carlsson, 2006; Ortt \& van der Duin, 2008). Researches show that deciding the type of innovation (product/ services, process, marketing, and organizational innovation) that a company wants to adopt depends mainly upon external forces (OECD, 2005).

Develop new vision, goals and objectives: At this stage of change, a company needs to review and revise its current vision, goals and objectives (Hammer \& Stanton, 1995; MacIntosh, 2003; Motwani, Kumar, Jiang, \& Youssef, 1998). This is a very crucial stage of organizational change; therefore, it requires visionary and dynamic competencies among top management for forecasting the future more accurately (Abdolvand et al., 2008).

Reengineer business process: Design a reengineering process (Harrison \& Pratt, 1993), launch problem solving project (Furey, 1993), and transform the organization process (Loukis, Pazalos, \& Georgiou, 2009; Manganelli \& Klein, 1994) is what a literature suggests at this stage. During this stage, before implementing a reengineered process, it is suggested to go thorough pilot testing in a particular area of an organization.

Implementation: This stage is very sensitive as most of the time failures occur at the transformation from planning to implementation (Al-Mashari et al., 2001). Therefore, strong leadership, collaborating work environment, top management commitment, use of IT, employees training, communication, education, building efficient teams, role of HR department in organization development, and employees commitment are very important for the successful implementation (Ahmad et al., 2007; Al-Mashari \& Zairi, 1999; Habib, 2011; Herzog, Polajnar, \& Tonchia, 2007; Magutu, Nyamwange, \& Kaptoge, 2010). 
Follow-up and continuous improvement through TQM: Organization require continuous evaluation and wherever changes are needed for improvement should be timely conducted. TQM plays a vital role at this stage and shall be used as a tool for continuous improvement. TQM is a comprehensive approach that is used to make sure that the organizations work properly. It involves all the departments and workforce with the support of customers and clients. Thus, TQM should be used for bringing quality in products and services (Grint, 1997; Motwani, 2001; Sheu, Yen, \& Krumwiede, 2003).

\section{Conclusion}

Change is taking place both at micro organizational level (internal environment) as well as macro level (external environment) which needs to be addressed, planned, and acted out carefully. The whole discussion of this study is intended to collect literature on change and processes of change for the purpose of demystification. Literature reveals that there are various tools for change with different perspectives and approaches; however, all are used for bringing planned change in an organization. This study also concludes that benchmarking will serve as a base for any change, whereas innovation is an essential tool for sustainability and to remain in competition. BPR is a radial and one time activity which can be followed by TQM, which is a continuous activity. Thus, if all change processes are integrated and utilized in a proper manner, it will provide fruitful results. Therefore, at the end, a consolidated model for change is suggested that is developed under the light of available literature and on the basis of recommendations of various studies.

One of the avenues for further investigation in this field is to test the model empirically and to polish the consolidated model for an integrated planned change process. More detailed and empirical studies are required to investigate the ground realities and practical approaches adopted by organizations in developed as well as developing countries.

\section{References}

Abdi, N., Zarei, B., Jamshid, V., \& Parvin, B. (2011). Innovation models and business process redesign. International Business and Management, 3(2), 147-152.

Abdolvand, N., Albadvi, A., \& Ferdowsi, Z. (2008). Assessing readiness for business process reengineering. Business Process Management Journal, 14(4), 497-511.

Ahire, S. L., Golhar, D. Y., \& Waller, M. A. (1996). Development and validation of TQM implementation constructs. Decision sciences, 27(1), 23-56.

Ahmad, H., Francis, A., \& Zairi, M. (2007). Business process reengineering: critical success factors in 
higher education. Business Process Management Journal, 13(3), 451-469.

Al-Mashari, M., Irani, Z., \& Zairi, M. (2001). Business process reengineering: A survey of international experience. Business Process Management Journal, 7(5), 437-455.

Al-Mashari, M., \& Zairi, M. (1999). BPR implementation process: An analysis of key success and failure factors. Business Process Management Journal, 5(1), 87-112.

Amis, J. M., \& Aïssaoui, R. (2013). Readiness for change: An institutional perspective. Journal of Change Management, 13(1), 69-95.

Anand, G., \& Kodali, R. (2008). Benchmarking the benchmarking models. Benchmarking: An International Journal, 15(3), 257-291.

Anderson, D., \& Anderson, L. A. (2001). Beyond change management: Advanced strategies for today's transformational leaders. San Francisco: Pfeiffer.

Archer, R., \& Bowker, P. (1995). BPR consulting: An evaluation of the methods employed. Business Process Re-engineering $\mathcal{E}$ Management Journal, 01(02), 28-46.

Arrowsmith, J., Sisson, K., \& Marginson, P. (2004). What can 'benchmarking' offer the open method of co-ordination? Journal of European Public Policy, 11(2), 311-328.

Asrofah, T., Zailani, S., \& Fernando, Y. (2010). Best practices for the effectiveness of benchmarking in the Indonesian manufacturing companies. Benchmarking: An International Journal, 17(1), 115-143.

Babbar, S., \& Aspelin, D. J. (1994). TQM? It's as Easy as ABC. The TQM Magazine, 6(3), 32-38.

Bhandiwad, V. S. (1998). Human side of re-engineering. Indian Journal of Industrial Relations, 34(2), 223-238.

Bhutta, S. K., \& Huq, F. (1999). Benchmarking - best practices: An integrated approach. Benchmarking: An International Journal, 6(3), 254-268.

Black, S. A., \& Porter, L. J. (1996). Identification of the critical factors of TQM. Decision sciences, 27(1), 1-21.

Bogan, C. E., \& English, M. J. (1994). Benchmarking for best practices: Winning through innovative adaptation. New York: McGraw-Hill.

Cao, G., Clarke, S., \& Lehaney, B. (2001). A Critique of BPR from a holistic perspective. Business Process Management Journal, 7(4), 332-339.

Carlsson, B. (2006). Internationalization of innovation systems: A survey of the literature. Research Policy, 35(2006), 56-67.

Castellani, D., \& Zanfei, A. (2003). Technology Gaps, Absorptive Capacity and the Impact of Inward Investments on Productivity of European firms. Economics of Innovation and New Technology, 12(6), 555-576.

Clarke, A., \& Manton, S. (1997). A benchmarking tool for change management. Business Process Man- 
agement Journal, 3(3), 248-255.

Cummings, T. G., \& Worley, C. G. (1997). Organizational Development and Change. Ohio: SouthWestern College Publishing.

Dattakumar, R., \& Jagadeesh, R. (2003). A review of literature on benchmarking. Benchmarking: An International Journal, 10(3), 176-209.

Deros, M. B., Yusof, M. S. r., \& Salleh, M. A. (2006). A benchmarking implementation framework for automotive manufacturing SMEs. Benchmarking: An International Journal, 13(4), 396-430.

Dervitsiotis, N. K. (2000). Benchmarking and business paradigm shifts. Total Quality Management, 11(4-6), 641-646.

Fazel, F. (2003). Quality Management systems: TQM vs.BPR. Quality Progress, 36(10), $59-62$.

Flynn, B. B., Schroeder, R. G., \& Sakakibara, S. (1994). A framework for quality management research and an associated measurement instrument. Journal of Operations management, 11(4), 339-366.

Furey, R. T. (1993). A six step guide to process reengineering. Planning Review, 21(2), 20-23.

GonzaÂlez-Benito, J., Martinez-Lorente, A. R., \& Dale, B. G. (1999). Business process re-engineering to total quality management: An examination of the issues. Business Process Management Journal, 5(4), 345-358.

Grint, K. (1997). TQM, BPR, JIT, BSCs and TLAs: Managerial waves or drownings? Managemenet Decision, 35(10), 731-738.

Habib, M. N., \& Jamal, W. (2013). Business process reengineering (BPR) initiatives in public sector of Pakistan. Business $\mathbb{E}$ Economic Review, 5(1), 89-121.

Habib, N. M. (2011). Role of training and teamwork in the successful implementation of BPR, Business Process Reengineering: A case of public sector of Khyber Pakhtunkhwa (KPK): VDM Verlag Dr. Müller

Habib, N. M. (2013). Understanding critical success and failure factors of business process reengineering. International Review of Management and Business Research, 2(1), 1-10.

Habib, N. M., \& Wazir, I. M. (2012). Role of education and training in the successful implementation of business process reengineering: A case of public sector of Khyber PakhtunKhwa (KPK). World Journal of Social Sciences, 2(2), 172-185.

Hammer, M. (1990). Reengineering work: Don't automate, elaborate. Harvard Business Review, July-August, 104-112.

Hammer, M., \& Stanton, S. A. (1995). The reengineering revolution: A handbook: HarperBusiness.

Harrison, D. B., \& Pratt, D. M. (1993). A methodology for reengineering business. Planning Review, 21(2), 6-11. 
Harvey, S., \& Millett, B. (1999). OD, TQM and BPR: A comparative approach. Australian Journal of Management $\mathcal{E}$ Organisational Behaviour, 2(3), 30-42.

He, X. J. (2004). The ERP challenge in China: A resource based perspective. Information system Journal, 14(2), 153-167.

Heraclitus. (500 B.C, 05/07/2005). The doctrine of flux and the unity of opposites. Retrieved 24/09, 2012, from http://www.iep.utm.edu/heraclit/\#H3

Herzog, N. V., Polajnar, A., \& Tonchia, S. (2007). Development and validation of business process reengineering (BPR) variables: A survey research in Slovenian companies. International Journal of Production Research, 45(24), 5811-5834.

Huang, Z., \& Palvia, P. (2001). ERP implementation issues in advanced and developing countries. Business Process Management Journal, 7(3), 276-284.

Lee, S. M., \& Asllani, A. (1997). TQM and BPR: Symbiosis and a new approach for integration. Managemenet Decision, 35(6), 409-416.

Light, N. J. (2004). The relationships and effects of employee involvement, employees empowerment, and employee satisfaction by job type in a large manufacturing environment. (Doctor of Philosophy), Capella University.

Loukis, E., Pazalos, K., \& Georgiou, S. (2009). An empirical investigation of the moderating effects of BPR and TQM on ICT business value. Journal of Enterprise Information Management, 22(5), 564-586.

Macdonald, J. (1995). Together TQM and BPR are winners. The TQM Magazine, 7(3), 21-25.

MacIntosh, R. (2003). BPR: Alive and well in the public sector. International Journal of Operations $\mathcal{E}$ Production Management, 23(3), 327-344.

Magutu, P. O., Nyamwange, S. O., \& Kaptoge, G. K. (2010). Business process reengineering for competitive advantage; key factors that may lead to the success or failure of the bpr implementation. African Journal of Business $\mathcal{E}$ Management, 1, 135-150.

Manganelli, L. R., \& Klein, M. M. (1994). The reengineering handbook: A step-by-step guide to business transformation. New York: American Management Association.

Martínez-Lorente, A. R., Dewhurst, F., \& Dale, B. G. (1998). Total quality management: Origins and evolution of the term. The TQM Magazine, 10(05), 378-386.

Martínez-Lorente, R. A., Dewhurst, F., \& Dale, B. G. (1999). TQM and business innovation. European Journal of Innovation Management, 2(1), 12-19.

Martinsons, M. G. (2004). ERP in China: One package, two Profiles. Communication of the ACM, 47, 65-68.

Mayer, R. J., \& DeWitte, P. S. (1999). Delivering results: Evolving BPR from art to engineering. In Business Process Engineering (pp. 83-129). Springer US.

McKay, A., \& Radnor, Z. (1998). A characterization of a business process. International Journal of Operations $\mathcal{E}$ Production Management, 18(9/10), 924-936. 
Melville, N., Kraemer, K., \& Gurbaxani, V. (2004). Review: Information technology and organizational performance: An integrative model of IT business value. MIS quarterly, 28(2), 283-322.

Miller, R. (1994). Global R\&D networks and large scale innovations: The case of automobile industry. Research Policy, 23(1), 27-46.

Motwani, J. (2001). Critical factors and performance measures of TQM. The TQM Magazine, 13(4), $292-300$.

Motwani, J., Kumar, A., Jiang, J., \& Youssef, M. (1998). Business process reengineering: A theoretical framework and an integrated model. International Journal of Operations $\mathcal{E}$ Production Management, 18(9), 964-977.

Muthu, S., Whitman, L., \& Cheraghi, H. S. (1999). Business process reengineering: A consolidated methodology. International Conference on Industrial Engineering Theory, Applications and Practice, San Antonio, Texas, USA, 05.

NG, J. K. C., IP, W. H., \& LEE, T. C. (1999). A paradigm for ERP and BPR integration. International Journal of Production Research, 37(9), 2093-2108.

Niosi, J. (1999). The internationalisation of R\&D: From technology transfer to the learning organisation. Research Policy, 28, 107-117.

Oslo Manual: The Measurement of Scientific and Technological Activities - Guidelines for Collecting and Interpreting Technological Innovation Data. (2005).

Ortt, J. R., \& van der Duin, A. P. (2008). The evolution of innovation management towards contextual innovation. Emerald, 11.

Pfeffer, J., \& Sutton, I. R. (2006). Evidence-based management. Havard Business Review, 84, 62.

Riley, J. (2012, Wednesday 24 October, 2012). Benchmarking.

Powell, T. C. (1995). Total quality management as competitive advantage: A review and empirical study. Strategic Management Journal, 16(1), 15-37.

Rothwell, W., Prescott, R., \& Taylor, M. (1998). Strategic human resource leader: How to prepare your organization for the six key trends shaping the future. Palo Alto, CA: Davies-Black.

Salegna, G., \& Fazel, F. (1996). An integrative approach for selecting a TQM/BPR implementation plan. International Journal of Quality Science, 01(13), 6-23.

Saraph, J. V., Benson, P. G., \& Schroeder, R. G. (1989). An instrument for measuring the critical factors of quality management. Decision sciences, 20(4), 810-829.

Selladurai, R. (2002). An organizational profitability, productivity, performance (PPP) model: Going beyond TQM and BPR. Total Quality Management, 13(5), 613-619.

Sentanin, F. O., Santos, C. A. F., \& Jabbour, J. C. (2008). Business process management in a Brazilian 
public research centre. Business Process Management Journal, 14(4), 483-496.

Senthil, V., R. Devadasan, S. R., Selladurai, V., \& Baladhandayutham, R. (2001). Integration of BPR and TQM: Past, present and future trends. Production Planning $\mathcal{E}$ Control: The Management of Operations, $12(7), 680-688$.

Sheu, C., Yen, H. R., \& Krumwiede, D. (2003). The effect of national differences on multinational ERP implementation: An exploratory study. Total Quality Management E Business Excellence, 14(6), 641-657.

Sheua, C., Yenb, H. R., \& Krumwiedec, D. (2003). The effect of national differences on multinational ERP implementations: An exploratory study. Total Quality Management $\mathcal{E}$ Business Excellence, 14(6), 641-657.

Subramoniam, S., Tounsi, M., \& Krishnankutty, K. V. (2009). The role of BPR in the implementation of ERP systems. Business Process Management Journal, 15(5), 653-668.

Trott, P. (2008). Innovation management and new product development (4th ed.). Harlow, England: Pearson Education.

Underdown, D. R. (1997). An Enterprise transformation methodology (Doctoral dissertation, University of Texas at Arlington).

Varjonen, V. (2006). Management of early phases in innovation process: A case study of commercializing technology in a small enterprise. (Masters Thesis), University of Technology, Helsinki.

Zeinalnzehad, M., Sahran, S., Mukhtar, M., \& Pourrostam, T. (2010). Benchmarking implementation in SMEs; A literature review and a research agenda. Paper presented at the The 11th Asia Pacific Industrial Engineering and Management Systems Conference, The 14th Asia Pacific Regional Meeting of International Foundation for Production Research, Melaka.

Zeitz, G., Johannesson, R., \& Ritchie, J. E. (1997). An employee survey measuring total quality management practices and culture development and validation. Group $\mathcal{E}$ Organization Management, 22(4), 414-444. 